\title{
Dons da bruxa e trajetórias wiccanas: narrativas sobre ser e tornar-se uma bruxa moderna
}

\author{
ANDrÉa Osório
}

\begin{abstract}
resumo Os praticantes de wicca são em sua maioria mulheres e se designam como bruxa(o)s. Através de entrevistas observou-se uma trajetória religiosa que se inicia no âmbito da religião da família de origem, perpassa religióes estabelecidas no país, como a umbanda e o espiritismo kardecista, até desaguar no universo Nova Era. Ao se identificarem como bruxas, as entrevistadas redesenham seu passado de forma a resgatar eventos nos quais o poder da bruxa é posto em evidência. Algumas identificam este poder em parentas, dando maior legitimidade à "nova" identidade, embora se diga ser bruxa "desde sempre".
\end{abstract}

palavras-chave Wicca. Bruxaria. Identidade. Nova Era. Gênero.

\section{Introdução}

Longe das acusaçóes de malefício tão comuns ao universo da bruxaria ${ }^{1}$, os praticantes de wicca se veem como bruxos modernos. Religiosidade ligada ao escopo de influência da Nova Era, a wicca tem se desenvolvido no país de forma mais marcante a partir da década de 1990. Entre outros fatores que contribuem para esse desenvolvimento está a facilidade de contato propiciada pela Internet e a publicação de livros sobre o assunto em português. Grupo religioso minoritário, com sujeitos oriundos de diferentes $b a$ ckgrounds religiosos, os wiccanos provavelmente não formariam um grupo nacional sem os instrumentos da rede mundial de computadores.

Entre 1999 e 2000, estudou-se o grupo através de entrevistas com bruxas residentes na região do Rio de Janeiro e através de mailing lists (Internet). A partir das informaçôes coletadas, observou-se uma trajetória religiosa que se inicia no âmbito da religião da família de origem, perpassa religióes estabelecidas no país como o catolicismo, a umbanda e o espiritismo kardecista, até desaguar no universo Nova Era, com sua multiplicidade de opçóes, dentre as quais a wicca emerge como possibilidade.

Percebe-se que os praticantes, autodenominados wiccanos ou bruxas ${ }^{2}$, são em sua maioria mulheres. Operam dentro da ideia de uma bruxaria moderna que retoma características da bruxaria tradicional, mas sem a ideia de acusação ou malefício. Utilizam concepções tradicionais sobre os gêneros, invertendo a valoração costumeiramente encontrada para ambos, dando ao feminino maior valor, o que se traduz na preeminência das mulheres em sua teologia e práticas rituais.

Ao se identificarem como bruxas, as wiccanas $^{3}$ entrevistadas apresentam seu passado à luz de suas novas crenças de forma a enfocar eventos nos quais o poder da bruxa é posto em evidência como, por exemplo, na habilidade de adivinhação do futuro. Algumas identificam este poder em parentas, dando maior legitimidade à identidade de bruxa, embora regularmente digam serem bruxas "desde sempre". Neste sentido, tanto um dom pessoal quanto a localização de uma bruxa na família são situaçóes recorrentemente encontradas entres as entrevistadas e que, segundo elas, apontam para seu status de bruxas. 
Não obstante algumas se imaginarem como bruxas "desde sempre", frequentemente dizem ter encontrado a bruxaria wicca após uma busca. Ao mesmo tempo, afirmam terem sido criadas em religióes majoritárias pelas suas famílias, em especial o catolicismo. Aparentemente contraditório, este discurso só pode ser compreendido quando se percebe que o dom da bruxa não necessariamente está relacionado ao aprendizado da ritualística wiccana. Assim, o dom é decodificado como um sinal de que se é bruxa, enquanto aprende-se a ser wiccano após um caminho longo de busca por uma religiosidade que expresse as concepçóes sobre o sagrado que a bruxa sente ter a priori.

Uma possível tensão entre o dom e o aprendizado, a magia e a religião, o tornar-se wiccana e o ser bruxa desde sempre se resolve quando se entende que este processo, conforme descrito pelas próprias bruxas, é rico e complexo, consistindo numa narrativa de autoapresentação como bruxa e, portanto, de identificação como tal, na qual não apenas a memória da trajetória vivida é relevante, mas também os marcos que indicaram à bruxa, em sua trajetória, qual o caminho que deveria trilhar. Assim, a análise empreendida aqui se baseia na narrativa de bruxas entrevistadas no Rio de Janeiro. Nestas narrativas, a bruxa refaz de modo linear, e através do discurso, sua trajetória, dando sentido às experiências vividas e realocando as experiências de membros de sua família como fontes relevantes que demonstram que se é uma bruxa.

O objetivo deste artigo é apresentar as trajetórias das bruxas entrevistadas de forma a permitir a compreensão da construção da identidade de bruxa wiccana a partir, sobretudo, da noção de dons. A wicca é uma vertente da Nova Era pouco analisada no âmbito das Ciências Sociais brasileiras. Nesse sentido, trata-se também de uma contribuição ao tema que permita conhecer melhor este grupo religioso, analisando algumas de suas concepçóes.

\section{O que é wicca?}

A wicca é parte de um ramo da Nova Era chamado por Heelas (1996) de "conhecimento da Deusa", alinhada com uma espiritualidade feminista e com fortes preocupações ecológicas. Tentando um resgate da tradição mágica europeia, a wicca reformula muito desta tradição e se abre à inclusão de elementos de qualquer origem espaço-temporal ${ }^{4}$. Para seus seguidores, ela é uma religião pagã herdeira das tradiçôes e crenças das comunidades europeias anteriores ao cristianismo (Grimassi, 2000). Alguns autores traçam uma linhagem que viria diretamente da pré-história para os dias atuais, outros acreditam que a wicca foi formulada na Inglaterra, na década de 1950.

Em sua cosmologia ${ }^{5}$ a wicca professa a crença em um par divino, a Deusa e o Deus. A Deusa teria dado origem ao Deus e ambos teriam criado o universo e todas as coisas nele - ou seriam o próprio universo, a própria natureza. Sendo a primeira, Ela tem preeminência sobre Ele, visto como seu filho e consorte, e essa preeminência se reflete nas práticas da wicca. Por isto, nos rituais, o lugar de destaque e liderança deve ser, tradicionalmente, de uma mulher. Encarnando princípios da natureza, esse par se torna doador de vida. A Deusa é associada à terra, às águas e à lua. $\mathrm{O}$ Deus é associado ao sol, ao céu, aos animais e à vegetação. Eles representam princípios opostos, mas complementares. A Deusa, como terra, deve ser fertilizada por seu consorte, o Deus, que representa o sol. Ambos são divindades da natureza e operam segundo os ciclos naturais (solares).

Vista pelas bruxas como sujeito mais próximo à natureza, a mulher guarda, na wicca, um 
DONS DA BRUXA E TRAJETÓRIAS WICCANAS $\mid 53$

local privilegiado para a atuação mágica, especialmente a bruxaria. Outros praticantes de magia como feiticeiros, magos e xamãs são sempre referidos na forma masculina, enquanto as bruxas são referidas na forma feminina. Estes outros sujeitos foram descritos pelas bruxas entrevistadas como simples operadores de magia, e não como membros de uma religião da natureza, como às vezes definem a wicca. Exceção deve ser feita ao xamã, que é visto como um ser ainda mais conectado à natureza do que as próprias bruxas, mas cuja atuação difere da delas. Nesse sentido, a bruxaria é frequentemente descrita por seus praticantes como uma religiáo da terra, exatamente como o xamanismo, terra e natureza ganhando significados associados à divindade feminina na wicca.

Os wiccanos atribuem ao masculino os papéis ativos: a guerra, a força, a luz, o selvagem. Ao feminino estão guardados os atributos da passividade, da fragilidade, da loucura, da escuridão e da cultura. $\mathrm{O}$ último par propóe que, na wicca, a valoração de gênero está construída de forma inversa àquela presente em nossa sociedade, colocando-se o feminino numa posição superior ao masculino. A civilização, a sofisticação da cultura, é apresentada como um atributo feminino, enquanto o masculino seria tosco, rude, selvagem. É fácil encontrar autores wiccanos e bruxas que acreditam que a bruxaria é proveniente de uma época da humanidade em que a sociedade se organizava em modelos matriarcais. Essa ideia corrobora a hipótese de que essa é uma religião centrada no feminino. O que se torna patente nos discursos elaborados pelas bruxas a respeito de sua própria história é que esta se constrói sempre em território europeu, está vinculada a um passado mítico ou distante, se organiza pela procura do tradicional como um conceito legitimador e é centrada no feminino.

\section{Trajetórias religiosas}

As entrevistas com bruxas da regiáo do Rio de Janeiro permitem perceber de forma mais profunda como a trajetória da bruxa a leva até a wicca. Se a trajetória é narrada enquanto tal e frequentemente sob a ideia de uma busca, a própria noção de busca é um dos fatores que permitem que se diga ser bruxa desde sempre. A busca traduz uma trajetória que só alcança seu fim quando a religião que a bruxa sente ser a mais adequada para si, isto é, aquela que está de acordo com sua percepção subjetiva do sagrado e de si própria, é encontrada. As religióes intermediárias são pontos de passagens nesta trajetória, nunca pontos de chegada. Ao mesmo tempo, as entrevistas apresentam a família de origem da bruxa - frequentemente mãe, pai ou padrasto - como formada por pessoas que apresentam, igualmente, trajetórias de mudança de religiosidade. Assim, tais trajetórias não são privilégio das entrevistadas, mas parecem constituir um fenômeno contemporâneo. A seguir apresento cada entrevistada.

Vanessa $^{6}, 25$ anos, solteira e sem filhos, diz que sua família é católica, apesar de afirmar que sua mãe "faz macumba esporadicamente". O pai também é católico. $\mathrm{O}$ padrasto não possui religião. Ela foi educada pela família no catolicismo: foi batizada, fez a Catequese e a Primeira Comunhão. Apesar disso, afirma que sempre foi wiccana e que apenas não sabia como nomear essa ideia religiosa que possuía.

A partir dos 7 anos de idade, Vanessa começou a jogar cartas para ler o futuro sem que ninguém lhe ensinasse a técnica. Posteriormente, entre os 10 e os 11 anos, leu o Livro de São Cipriano ${ }^{7}$ (1996), um livro de magia facilmente encontrado à venda. Aos 13 anos, passou a jogar tarô. Leu Mônica Buonfiglio (1993, 1996) já na faculdade, uma autora de livros sobre anjos e almas gêmeas que foi best-seller na década de 1990. Após fazer um feitiço 
para se livrar da inimizade de uma moça - o qual afirma ter funcionado - passou a ler sobre magia em livros de Eliphas Levy (2003) e Papus $^{8}$ (1995), mas não se identificou com a magia descrita por estes autores. Passou a ler também sobre tarô. Nesta época, viu uma reportagem na revista Marie Claire sobre novas religiosidades e descobriu a wicca, mas devido à forma como esta foi apresentada, diz, ficou com a impressão de que seus praticantes não eram pessoas sérias. Mais tarde, ainda na faculdade, teve acesso à Internet e encontrou sites sobre a wicca. Apesar de seu primeiro contato com a wicca ter se dado através de uma revista, é através da Internet que Vanessa passa a estudar e compreender a bruxaria ${ }^{7}$. Nesse momento, se identificou com a wicca e descobriu que era wiccana. Passou, então, a ler livros sobre bruxaria wicca.

Ana, 28 anos, é solteira e tem duas filhas, uma de 5 anos e a outra de 2. Afirma que sua família é católica, religião na qual foi educada. Ela foi batizada e fez a Primeira Comunhão. Apesar disso, diz que antes de encontrar a wicca não tinha uma religião. Afirma que sempre foi wiccana, mas não sabia como nomear sua religião. Começou a jogar cartas intuitivamente aos 12 anos. Iniciou, entáo, seus estudos sobre esoterismo. Tinha premoniçôes e vidência e procurava uma explicação para esses fenômenos. Primeiro, buscou no espiritismo, depois na "magia cerimonial”, quando também leu Eliphas Lévy e Papus. Começou, então, a pesquisar sobre os ciganos, pois seu pai era filho de ciganos, embora não tenha aprendido a cultura cigana e tenha sido criado para ser padre, ingressando no Seminário, mas abandonando-o por fim.

A busca de Ana por conhecimento se estendeu às filosofias orientais e ao I Ching. Ela afirma que nenhuma dessas filosofias/religiōes era aquela com a qual se identificava, pois via Deus como uma mulher e procurava um caminho religioso que acreditasse nisso. Foi numa conversa com um amigo que ela descobriu a wicca e chegou à conclusão de que esta era a opção religiosa que vinha buscando. Ana passou, então, a ler uma literatura estrangeira específica sobre o assunto. Nesta época, começou a frequentar duas livrarias especializadas em livros esotéricos. Foi assim que descobriu que wicca e bruxaria eram a mesma coisa.

Durante a entrevista, recordou-se de que já havia lido um livro sobre bruxaria antes, escrito por Hans Holzer (1994), na biblioteca de seu colégio, em 1984, aos 12 anos de idade. Nessa época, afirma, não conseguiu aceitar o que o livro apresentava, pois era muito nova e o conteúdo repleto de simbologias sexuais a assustara. Ana só se tornou praticante de wicca quando conheceu outra bruxa, Inês, que trabalhava como vendedora na mesma loja que ela, em um shopping center da cidade.

Cíntia, 36 anos de idade, é casada e tem dois filhos: uma menina de 3 anos e um menino de 5. Sua família é Testemunha de Jeová. No entanto, como seu sonho era casar-se na Igreja Católica, Cíntia foi batizada no catolicismo e casou-se numa cerimônia católica. Hoje diz não saber qual a religião da mãe, se espírita ou católica. Cíntia diz que já frequentou a umbanda, o kardecismo e o budismo. Quando criança e adolescente, tinha visões e sonhos premonitórios. Só veio a encontrar a wicca anos mais tarde, através de um bruxo com quem conversava pela Internet. Este homem afirmou que ela era bruxa e lhe deu o endereço de um site de wicca. A partir daí afirma ter começado a estudar wicca, procurando livros sobre o assunto, embora diga que já então suspeitasse de que era bruxa.

Adriana, 31 anos, separada de seu primeiro marido há três anos, tem uma filha de 13 anos e um filho de 9. Afirma que o pai não tinha religião, acompanhava a mãe ao Centro Espírita (umbanda) e à Igreja Católica, e era devoto de 
Santa Edwiges. Sua mãe era umbandista, mas fez questão de que os filhos fossem batizados na Igreja Católica, onde deveriam também fazer a Catequese, ficando a cargo de cada um a opção de fazer ou não a Primeira Comunhão. Adriana diz que optou por não fazer. Mais tarde, ingressou na Igreja Messiânica, na qual se casou. Afirma que sempre foi "muito bruxa", possuindo uma "ligação muito forte com a lua desde o nascimento". Fez um ritual de cura, intuitivamente, para o filho que aos 3 anos de idade desenvolveu uma tuberculose ganglionar no pescoço, sob a forma de tumor, segundo ela. Os médicos não conseguiam curá-lo e Adriana tentou curas espirituais também sem sucesso. Esta foi alcançada através deste ritual, para ela um marco: "ali foi o ponto determinante da minha vida pra eu saber que eu era uma bruxa e que eu ia seguir isso". Passou, então, a buscar e estudar bruxaria. Quando encontrou a wicca, ainda participava da Igreja Messiânica.

Uma de suas primeiras leituras foi Brida, de Paulo Coelho (1990), quando se identificou com a personagem título do romance, que é uma mulher em busca de uma pessoa que lhe ensine bruxaria. Começou a frequentar livrarias e sebos procurando livros a respeito. Há seis anos, Adriana conheceu uma bruxa chamada Monique através de um anúncio em um jornal. Monique ia ministrar um curso sobre wicca, mas quando conheceu Adriana disse-lhe que não precisava de aulas, pois fazia tudo certo. Algum tempo depois, Adriana começou a frequentar uma grande livraria no centro do Rio onde conheceu alguns bruxos. Durante algum tempo essa livraria foi local de encontro de praticantes de wicca.

Carla, 32 anos de idade, é casada e não tem filhos. Afirma que a mãe é católica. Ela conta que seus ancestrais são possivelmente pagãos, ou seja, praticantes de bruxaria, embora ela não possa confirmar esta suposição. Foi criada pela mãe no catolicismo, frequentando colégios confessionais. No entanto, relata que desde pequena se sentia diferente das outras crianças. Diz que era capaz de ver e se comunicar com espíritos, tinha visóes, sonhos premonitórios e desenhava "quadrados mágicos". Começou a jogar cartas para prever o futuro intuitivamente aos 12 anos de idade e, posteriormente, ganhou um baralho de tarô. Aos 19 anos, na faculdade, leu alguns livros e conheceu pessoas ligadas à bruxaria.

Edna, 34 anos, é casada e não tem filhos. Sua mãe é umbandista e seu pai é baha’i. Foi batizada na Igreja Católica. Edna afirma que nunca praticou nenhuma outra religião que não a wicca. Afirma que a wicca é a única religiaao que "tem a ver com [sua] linguagem", principalmente por sua ênfase no feminino. Ela decidiu se tornar bruxa quando leu $A s$ Brumas de Avalon, de Marion Zimmer Bradley (1985), aos 15 anos, e se identificou com a religião descrita no livro, com o que afirma ser "a maneira mais feminina de ter contato" com a religião e passou a enxergar a divindade como feminina. Só ingressou na wicca de fato após ter-se mudado do Rio de Janeiro para o Rio Grande do Sul, onde conheceu uma taróloga que era bruxa. Ao vê-la buscando "a religião da Deusa”, esta amiga revelou que era bruxa.

Ronaldo, único homem entrevistado, 22 anos, casou-se com Edna em uma cerimônia wiccana. Este é seu segundo casamento. Ele já havia se casado (coabitação) antes, também com uma mulher mais velha do que ele. Ronaldo não tem filhos. Seu pai é católico, mas frequentou o kardecismo e a umbanda. A mãe é católica, mas se interessou por espiritismo e hoje estuda esoterismo e ufologia. Ele foi criado dentro do catolicismo, mas considera que a única religião que já praticou foi a wicca. Diz ler sobre ocultismo desde os 13 anos. Começou a jogar tarô e buscar livros sobre magia. Encon- 
trou um livro sobre wicca chamado Feitiçaria: a tradição renovada, de Evan John Jones e Doreen Valiente (1992), seu primeiro contato com a bruxaria, e continuou a pesquisar sobre o assunto. Quando conheceu uma amiga de sua mãe que era bruxa, passou a estudar com ela. Mais tarde, através de um anúncio no jornal, como Adriana, conheceu Monique, e através dela outras bruxas, incluindo Edna e Ana.

Entre as narrativas das bruxas entrevistadas, pontos comuns emergem, não apenas nas trajetórias pessoais como nas trajetórias de mães e pais. O contato com a wicca, porém, aparece sempre como exclusivo da bruxa, nunca compartilhado com a família de origem. Esse contato se dá, sobretudo, por intermédio de terceiros, de livros e de revistas. A Internet pode substituir o livro/revista como fonte de informação e facilitar o contato com demais bruxos. Interessante observar o papel que as livrarias exerceram na sociabilidade wiccana, presumivelmente em um período em que a Internet não era tão acessível e popular, conforme o relato de algumas bruxas que só tinham acesso à rede virtual na faculdade. Neste sentido, não foi questionado a nenhuma entrevistada quais leituras foram importantes no processo de busca pela wicca. Tal informação emerge recorrentemente de maneira espontânea, demonstrando o papel desempenhado por esta literatura para o grupo pesquisado.

Dentre os sete entrevistados, cinco afirmam terem dons antes mesmo de conhecerem o sistema ritual wiccano. Vanessa, Ana e Carla afirmam que podiam prever o futuro pelas cartas quando ainda crianças e sem ensinamento prévio. Cíntia e Carla afirmam que possuíam dons premonitórios, muitas vezes através de sonhos. Afirmam, ainda, que podem se comunicar ou ver espíritos. Adriana afirma que descobriu os rituais intuitivamente e que possui uma "ligação com a lua". Edna e Ronaldo não fizeram menção a dons pessoais. É interessante observar que os dons algumas vezes emergem no final da infância e início da adolescência, como se a liminaridade (Turner, 1974) contida no aspecto geracional correspondesse à posição liminar da bruxa.

Em sistemas religiosos outros que não a wicca tais dons seriam decodificados de forma semelhante e ao mesmo tempo distinta. Assim, no espiritismo, seria sinal de mediunidade, enquanto no candomblé seria sinal de obrigação para com um Orixá. Em ambos os casos, indicaria a necessidade de dedicação à religião em questão. Entre as entrevistadas, embora o dom indique que se é uma bruxa, não comporta um dever ou uma obrigaçáo de estar em uma religião, mas enseja uma busca por uma religião. É claro que, no Brasil, tanto o espiritismo quanto o candomblé ou a umbanda seriam de fácil acesso, fornecendo explicaçóes para os dons e, de fato, muitas entrevistadas passaram por estas religióes. Se a maior ou menor proximidade que elas guardam com tais religióes não é explicada em função de seus dons, é porque estes ganharam significado não para uma identidade de médium espírita ou filha de santo, por exemplo, mas para a identidade de bruxa.

Cabe aqui indicar que o universo Nova Era, do qual a wicca faz parte, é altamente individualizado. A religiosidade Nova Era foi definida como "religiosidade do Eu", que se refere tanto à falta de mediaçáo entre sujeito e divindade quanto ao fato de que o Eu é o lócus da divindade (Heelas, 1996). Amaral (1996; p.67) aponta, de um lado, uma "versão hard magia-poder [...] que enfatiza o par energia-poder [...] e tende a recriar o mito do indivíduo todo poderoso", e, de outro, "uma versão mais soft do movimento Nova Era que enfatiza o par espiritualidade-harmonia”. A wicca estaria localizada na primeira vertente.

Assim, a wicca é um sistema de bruxaria com um forte fator de individualismo: não é a sociedade ou o grupo ao qual a bruxa pertence 
que a aponta como bruxa como, por exemplo, entre os Azande (Evans-Pritchard, 1976), mas a própria bruxa que se sente como tal identifica-se desta forma e busca um sistema religioso com o qual sente uma afinidade. $\mathrm{O}$ encontro com a wicca é recorrentemente narrado desta perspectiva. Não se trata de um sistema tradicional de bruxaria. Do ponto de vista da bruxa, tampouco se trata de uma opção, mas sim do encontro com um sistema religioso que está afinado com uma realidade interna subjetiva.

\section{Os dons da bruxa}

Se as famílias das bruxas entrevistadas passam por trajetórias religiosas análogas às delas, embora não venham a ingressar na wicca, os dons também aparecem compartilhados em família. A maioria dos entrevistados declara algum parente como sendo bruxo, em geral as mulheres: tias, tias-avós, avós, irmãs, a mãe ou mesmo antepassados mais longínquos. Excepcionalmente, homens também podem ser apontados como bruxos: um pai cigano, por exemplo, ou um antepassado mítico. Carla, uma das entrevistadas, reformulou sua árvore genealógica de modo a fazer-se descendente do primeiro rei da Espanha, segundo ela uma figura mitológica ligada ao paganismo europeu pré-cristão. Também vinculou sua família ao aparecimento da bruxaria no Brasil, por volta da década de 1940.

Outros entrevistados não demandam parentesco tão nobre, mas afirmam que determinados parentes são bruxos, não necessariamente wiccanos, mas portadores de dons e/ou conhecimentos especiais, conforme as citaçóes abaixo ${ }^{8}$. A religião adotada pelo parente, ainda que não seja o paganismo, como na wicca, não invalida a identificação como bruxo. Segundo Mauss (1979), os mágicos formam, usualmente, castas ou corporaçóes recrutadas hereditariamente. Pode haver conhecimentos transmitidos em família ou necessidade de certas condições favoráveis para que o dom aflore.

Entende-se que a identidade de bruxa constitui identidade desviante, formada a partir de uma ruptura com as normas sociais (Mauss, 1974; Douglas, 1976), portanto o dom se torna parte da construção dessa identidade desviante, pois promove uma ruptura com o comum. A wicca segue a ideia de que o ritual e a magia são espaços que lidam com a desordem e a potência da desordem: sonhos, frenesis, a desordem da mente que permite acessar poderes e verdades que o esforço consciente não alcança (Douglas, 1976). Esta desordem é uma quebra com a razão. Retornando destas regióes desordenadas com novos conhecimentos, a bruxa adquire um poder inacessível aos outros. Movimentando-se entre a ordem e a desordem, ela toma uma posição marginal, perigosa. Ela se dispóe num estado de transição entre ambos. Ter estado nas margens é ter estado em contato com o perigo, com o poder (Douglas, $O p$. cit.). A bruxa tem uma posição marginal na sociedade: não é apenas definida segundo uma força psíquica, um dom, mas pode ser estruturalmente definida segundo seu status ambíguo e inarticulado. São pessoas em áreas relativamente não estruturadas da sociedade, onde o controle é difícil (Douglas, $O p$. cit.).

$\mathrm{O}$ operador de magia aparece, para Mauss (1974), também como um sujeito marginal. Não define a magia pela forma de seus rituais, mas pelas condições em que são realizados e que marcam o lugar que o mágico ocupa em sua sociedade. Náo fazendo parte de um culto organizado, ele toca o limite do proibido. É secreto, privado e misterioso. O que torna a magia eficaz é um poder desconhecido. Este poder provém de dons espirituais que qualificam o indivíduo para a prática mágica. Entre as bruxas entrevistadas, o recurso à ideia de dom reforça a condição de bruxa, ao mesmo tempo 
em que é um poder que legitima a prática da magia.

Minha mãe sempre foi meio bruxa, mas ela sempre ficou quieta, na dela e tal. A minha avó - a mãe da minha mãe - era bruxa, bruxa, bruxa, bruxona. Ela botava carta (Carla)!

Tem a minha avó, que passeia astralmente com uma facilidade danada e fala com todo mundo no astral, depois desce e conta (Ronaldo).

Bruxas? Muitas! Sem saber, totalmente inconscientes! A minha avó é uma bruxona [mas] ela não tem noçáo do poder dela. Se a gente, por exemplo, viaja e não leva ela, o carro não pega de jeito nenhum. Pode levar pra oficina, está tudo bem, mas o carro não pega. A Marta, a minha irmã, também faz isso quando briga com o namorado. Não é uma vez, são várias vezes que isso acontece. Isso acontece sempre. Por exemplo, se o namorado briga com ela, o carro dele náo pega enquanto ele não fizer as pazes. Náo adianta, se não conversar com ela, o carro não vai pegar. Minha mãe... não adianta você mentir pra ela, ela sabe exatamente o que está passando na sua cabeça. Uma vez eu fugi com o namorado. Eu tinha o quê? Uns 13 anos. Fui namorar na beira de um rio. Quando eu cheguei em casa, a minha mãe falou assim: "você não foi ao cinema, não foi tomar sorvete". $\mathrm{E}$ eu: "quê isso mãe!" Ela: “aonde você foi tinha água, era beira de um rio, tinha uma cerca que você tava perto dessa cerca”. A mãe da minha avó é profundamente católica, mas era uma católica muito bruxa. Achei na caixinha de carta dela vários feitiços com cabelo, com laço. $\mathrm{Na}$ cabeça dela, ela estava fazendo simpatia, ela não estava fazendo feitiço, entendeu? A mãe da tia Dora conversava com os espíritos o dia inteiro e quando ela precisava de um dinheirinho, ela perguntava qual era o bicho que ia dar pra eles e ela sempre ganhava. Sempre, sempre ganhava, eles sempre contavam pra ela. Se alguém precisasse de um dinheirinho, não era muito, mas [perguntava] "Dona fulana, qual é o bicho que vai dar hoje porque eu estou precisando de um dinheirinho?”. Aí ela perguntava pros espíritos e eles diziam. Essa foi a bruxa mais consciente mesmo, e era benzedeira. Minha tia-bisavó. Ela aprendeu, eu acho que [foi] com uma... Bom, essa parte da família, que é do sul, eles viveram muito tempo com uma ex-escrava que ensinava essas coisas de ervas pra ela, então tia Dora sabia muito, a mãe dela sabia muito por causa dessa escrava. Acho que vem daí (Edna).

A minha avó, ela tem muito de bruxa, apesar dela não saber e achar que é abominante falar que é uma bruxa. Ela tem muito de bruxa porque ela sempre fez feitiço, ela sempre fez magia, sempre fez coisa, mas ela nunca se colocou como bruxa, até porque, na época dela, ser bruxa era mais triste do que é hoje. Hoje em dia [se] fala que é bruxa, tu acha até que é moda, mas naquela época não, bruxa era bruxa mesmo e fazia feitiço pro mal, mas minha avó era muito bruxa. Ela dizia que era simpatia, entendeu? Ela achava que era simpatia, mas eu sei que na verdade eram feitiços porque você pode procurar em livro de simpatia que você não acha nenhuma simpatia dessas, entendeu? Eram simpatias que ela dizia "aprendi com a minha mãe", porque a mãe dela era índia, e... cabocla, né, sei lá se era índia, e contam, né, que foi pega a laço pelo meu bisavô (Adriana).

A bruxa localizada entre os parentes pode ser "meio" bruxa ou "muito" bruxa, e pode ter "consciência" de seus dons e de que é bruxa ou não. Selecionei apenas algumas passagens das entrevistas, mas entre os dons destacados, encontram-se ainda: vidência ou capacidade de profetizar o futuro e/ou o passado; intuição; capacidade de ver e/ou se comunicar com seres como espíritos, vento, fadas, árvores; co- 
nhecimento intuitivo, que consiste em saber procedimentos tidos como mágicos ou típicos de bruxas, feiticeiros ou magos, sem que esses conhecimentos nunca tenham sido ensinados à pessoa em questão; projeção astral; poder espiritual; campo áurico diferente; poder de matar alguém com o olhar; poder de mudar o curso do destino; poder de modificar situaçôes; poder de interferir na matéria (desligar um carro, fazer alguém cair ou movimentar a cama apenas com alteraçóes de humor ou com a força exclusiva da vontade); potencial de cura; poder de evitar doenças, confrontos e problemas; percepção energética; magia. Estes dons foram elencados pelas entrevistadas ao se referirem, sobretudo, a membros de sua família consideradas bruxas. É interessante que, ao contrário do que poderia presumir um senso comum, a bruxa não se define exclusivamente pela utilização de feitiços.

A bruxaria em família, no entanto, não se limita aos antepassados. As entrevistadas que têm filhos declaram, muitas vezes, que suas filhas são bruxas. Adriana, porém, recusa a possibilidade de bruxaria aos filhos, embora tenha apontado algumas irmãs como possíveis bruxas. Mais recentemente, contudo, soube que sua filha tornou-se wiccana.

Eu acho até que [minhas filhas] já são [bruxas]. Inclusive, né, a Daniela, que é a mais velha, porque quando eu me iniciei, eu estava grávida dela, né, entấo ela já nasceu bruxa. Ela já recebeu a ordenação dentro do meu ventre, né (Ana).

Minha filha é uma bruxa. Ela vai ser uma bruxa. Ela nasceu bruxa, ela tem o dom de bruxa, e se ela vai querer ser uma bruxa ou não, ela vai escolher sozinha (Cíntia).

Como esses parentes são reconhecidos como bruxos? Seguindo o discurso das entrevistadas, observa-se que seis delas acreditam que a bruxaria é um dom (também referido por elas como poder ou potencial), constitui um poder inerente à bruxa, dado desde sempre e que ela possui desde o seu nascimento. Uma entrevistada acredita na herança familiar como um dado importante da obtençáo do dom. Dois entrevistados afirmam que todas as pessoas são bruxas em potencial, bastando apenas desenvolver os dons. Outras duas entrevistadas creem que todas as mulheres são bruxas, pois a bruxaria seria inerente a elas. Uma entrevistada acredita que a bruxaria é uma escolha entre desenvolver ou não estes dons (é uma escolha, mas também um dom). Uma entrevistada afirma que a bruxa ou o bruxo é simplesmente aquele que lida com magia, não apresentando necessariamente nenhum dom naturalmente dado e apenas esta entrevistada não acredita na bruxaria como um dom, mas como fruto do esforço de aprendizagem da magia.

Quando eu falo bruxa, pra mim é aquela que tem o poder de modificar as coisas. A minha avó já tinha, minha mãe, minha bisavó. [O poder] nasce com ela. Eu não acredito que você adquire (Vanda).

É, eu te falei que toda mulher já é. É bruxa por natureza e ela só precisa acender aquilo, né. Se tem ventre, é bruxa (Ana).

Todas as mulheres são bruxas em potencial (Carla).

$\mathrm{Na}$ verdade, se você buscar dentro de você o poder interior, você vai descobrir um dom seu, uma bruxaria, um potencial dentro de você, que você dá o nome que você quiser: paranormalidade, é um potencial, um dom extrassensorial. A diferença é que uma tem consciência do que é e a outra não, mas a maioria das pessoas sabe. Eu acho que as pessoas nascem [bruxas]. Elas só são esquecidas (Edna). 
6o | ANDrÉa Osório

Eu me defino como wicca sim, porque wicca é bruxa, ser wicca e ser bruxa não tem diferença pra mim não, entendeu? A magia é uma coisa que vem muito naturalmente. Quando você começa a praticar magia, você descobre que você sabe tudo. É como se a gente tivesse relembrando. A gente sempre fala que a bruxa, ela relembra porque ela foi [bruxa] uma outra vez, numa outra vida (Adriana).

Como alguém se torna uma bruxa? Parafraseando e invertendo Simone de Beauvoir (1949), parece que se nasce bruxa, não se torna uma. As mulheres, segundo Carla e Ana, não apenas nasceriam mulheres como já nasceriam bruxas. Para Adriana, uma bruxa está destinada a sê-lo, encarnação após encarnação. Para Edna, contudo, os dons são mais democráticos, pois cada pessoa teria o seu. Tornar-se bruxa seria, então, uma questão de tomar consciência deste dom.

O dom aparece como uma atividade não racional, um poder do qual se pode não ter consciência. Assim, pode-se analisar o problema do dom na constituição do ser bruxa a partir da oposição entre razão e emoção/intuição. De fato, em toda a Nova Era, e também na wicca, a razão é questionada, desvalorizada e às vezes evitada em prol da emoção, da intuição e do lúdico. Muitas das práticas que compóem o universo Nova Era utilizam tal dicotomia e desvalorizam a razáo, o mesmo ocorrendo na wicca. Em quase todas as atividades da Nova Era é possível observar um esquema binário de organização do mundo que opóe dois conjuntos: de um lado a natureza e de outro a civilização. Segundo Carozzi (1999), no lado "natureza", observam-se agrupados os seguintes elementos, mais valorizados e sacralizados pela Nova Era: passado, magia/rito/mito, arte, feminino, infância, Oriente, indígenas, corpo, inconsciente, intuição, receptibilidade, sensação/emoção, prazer, espontaneidade, ritmo, gesto/movimento/contato, manipulação direta. No lado "civilização", apresentam-se os seguintes elementos: presente, cultura, ciência, tecnologia, masculino, maioridade, Ocidente, europeus, mente, consciente, racionalidade, crítica, intenção/vontade, esforço, controle, melodia, palavra, máquinas e ferramentas. A sacralização do lado "natureza" evidencia uma inversão da valoração que atribui ao progresso, à racionalidade e à tecnologia papéis centrais na transformação positiva do mundo, predominante na década de 1950 (Carozzi, 1999).

Especificamente para a wicca, a razão é vista como masculina e o masculino está associado, ainda, ao capitalismo, à opressão, à violência e à ciência, todos desvalorizados, pois esta religiosidade tende a valorizar aquilo que considera feminino, como as emoções, a magia e a natureza. O dom é localizado em mulheres porque ele retrata uma concepção de mundo. É visto essencialmente como uma característica feminina na medida em que os dons em questão são sempre de natureza não racional, intuitiva, sobrenatural ou mágica. Há aqui uma essencialização do feminino e do masculino tanto quanto uma essencialização da bruxa. Não se é bruxa em relação a alguma coisa: nasce-se bruxa, é-se bruxa desde sempre, foi-se bruxa em vidas passadas. $\mathrm{O}$ dom é uma característica da bruxa, nasce com ela, latente ou desenvolvido. Ao mesmo tempo, a wicca emerge como uma busca pessoal, mas uma busca por algo que se sente, uma religiosidade intuída que precisa ser buscada fora da subjetividade, que precisa ser alcançada como uma realidade tangível, praticada por outros.

\section{A "bruxa hereditária"}

Embora o dom possa ser inato, dado desde o nascimento ou oriundo de vidas passadas, compreendido como um potencial pessoal que 
também aparece em outros membros da família da bruxa, nenhuma entrevistada afirma haver outro wiccano na família e, ao contrário, afirmam claramente que a wicca foi encontrada após uma busca. Assim, aquela que diz ter aprendido a bruxaria em família é mal vista entre as entrevistadas 9 . Este tipo de bruxa é chamado, entre os wiccanos, de "bruxa hereditária”. Hereditário, aqui, não se refere a inato, mas a aprendizado.

"Ah, eu sou especial, eu sempre fui bruxa, eu tive uma vida de bruxaria desde criança porque a minha mãe me ensinou a ser bruxa”. Não, não é assim, sabe? A cada mil, uma teve a mãe do lado pra poder ensinar, entendeu (Carla)?

Aprendi muita coisa com ela [a avó]. Aprendi muito [do] que eu uso como bruxa. [Mas] Eu acho que eu seria uma "bruxa hereditária" se eu tivesse desenvolvido isso porque minha avó era bruxa, entendeu, e não foi assim. Não foi porque minha avó era bruxa e passou os conhecimentos pra mim, então eu não me considero uma "bruxa hereditária" (Adriana).

A suspeição que recai sobre a "bruxa hereditária” é de diversos níveis. Primeiro, as entrevistadas têm perfeita noção de que a wicca é um sistema recém-chegado ao Brasil, sendo assim nenhum antepassado poderia ser wiccano, embora possa ser considerado bruxo no sentido de possuir dons e efetuar feitiços. Segundo, sabem que a bruxaria está associada, segundo a tradição popular, com o malefício e por isto um antepassado dificilmente se apresentaria como bruxo. A partir daí, seria ainda mais raro que ensinasse bruxaria a alguém, formando uma nova bruxa de forma consciente. Não se nega, contudo, que raros casos possam ter ocorrido. Terceiro, como tal situação seria uma exceção, sempre se suspeita de quem afirma ser "bruxa hereditária”, presumindo-se que é uma men- tira. Aqui se deve levar em consideração, ainda, que ser uma "falsa bruxa" é uma acusação comum no universo pesquisado e desmerece a pessoa em questão, retirando-a do campo. Trata-se, contudo, de uma acusação característica de situaçóes de disputa nas quais funciona como uma estratégia (Osório, 2005).

Por um lado, portanto, a hereditariedade da bruxa, no sentido do aprendizado em família, é desvalorizada em função de uma supervalorização do individual, na forma dos dons pessoais e da busca pessoal pela bruxaria; por outro, a hereditariedade é valorizada, pois consiste em atestado de que se é oriundo de uma família de bruxas. Parece-me que é nesta tensão que reside a necessidade de se localizar uma bruxa na família como forma de legitimar uma identidade de bruxa e, ao mesmo tempo, negar o aprendizado da bruxaria em família. Esta negação não reside apenas no estado de exceção que constituiria, mas numa desvalorização da busca pessoal.

Conforme as passagens acima, Adriana, por exemplo, localiza uma bruxa na família - a avó - que, no entanto, não se identificava como bruxa, pois associava bruxaria a malefício. Esta avó, contudo, era filha de uma índia, que lhe teria ensinado procedimentos mágicos compreendidos como "simpatias". Para Adriana, contudo, tais simpatias são feitiços, pois ela não os reconheceu em revistas com receitas de simpatias vendidas comumente nas bancas de jornais. Sendo feitiços, são efetuados por uma bruxa. O feitiço aparece aqui, como na narrativa de Edna acima, como outro elemento para localizar uma bruxa na família. A bruxa, portanto, é aquela que faz feitiços e/ou possui certos dons.

Não obstante, há uma tensão entre dom (inato) e hereditariedade (aprendizado), tensão que se reproduz em diversos níveis. $\mathrm{O}$ dom se torna distinto do aprendizado, constituindo a oposição necessária à compreensão de como se 
pode ser bruxa "desde sempre" e, ao mesmo tempo, buscar alguém que lhe ensine a wicca; tensão também presente na ideia de que há outras bruxas na família, mas não se é uma bruxa hereditária, ainda que se afirme ter aprendido procedimentos mágicos com tais parentes, como Adriana faz.

A tensão entre inato e aprendido se apresenta, ainda, na forma como o sistema wiccano é adotado. Das entrevistadas, apenas Adriana afirma que descobriu os rituais sozinha, intuitivamente. Em geral, afirma-se que a bruxaria foi aprendida em livros, por meio da Internet ou através de outras bruxas. A tensão formada entre ser bruxa (dons) e ser wiccana (aprendizado) se resolve na busca que é empreendida pelas bruxas por serem bruxas, isto é, por terem dons, e para serem wiccanas, isto é, para aprenderem um sistema ritual que explorará seus dons e atribuirá certos significados a eles. Esta separação entre as categorias bruxa e wiccano, contudo, não se apresenta formalmente no universo pesquisado, mas confunde-se. Assume-se, a priori, que wicca e bruxaria são a mesma coisa, ainda que a bruxaria praticada por um membro da família seja de origem indígena ou africana ${ }^{10}$ e a wicca propriamente dita seja de origem europeia. Para Adriana, que entre todas as entrevistadas parece ter resolvido melhor esta tensão, "wicca é apenas um nome" dado a uma prática antiga e o nome, certamente, importa menos do que a prática.

\section{Consideraçóes finais}

A presente reflexão visa contribuir para a compreensão da conversão a este grupo religioso, especialmente das mulheres, as quais parecem consistir na maioria dos praticantes de wicca. Esta adesão constrói-se de forma subjetiva, mas também por meio de uma reformulação da própria trajetória como marcada por eventos que legitimam a identidade de bruxa, sobretudo aqueles relacionados ao que classifiquei aqui como dons da bruxa.

O dom constitui indício legitimador da condição de bruxa. O dom de jogar cartas, a mediunidade, a intuição levam a caracterizar uma conduta desviante propícia à prática mágica (Mauss, 1974). O dom e a ideia de que há bruxas na família são formas de legitimação da identidade de bruxa entre as wiccanas entrevistadas. Quanto à família, a bruxa aparece prioritariamente como uma mulher que pode saber ou não que é ou foi bruxa. Não diz respeito a uma condição assumida pelo parente em questão. Há uma história familiar que é contada de modo a localizar uma bruxa na família. No que tange aos dons, percebe-se que as entrevistadas tendem a assumir esta mesma posição: experiências de vida são contadas de modo a indicar que a entrevistada em questão já nasceu bruxa ou que é bruxa desde sempre. É esse posicionamento que permite a elas afirmarem que não tinham religião alguma anterior à wicca.

Como a identidade de bruxa está intimamente ligada com uma determinada identidade feminina ("se tem útero é bruxa", conforme uma entrevistada), e como a identidade feminina na sociedade brasileira é dada prioritariamente nas relações em família (Goldenberg, 1992), é compreensível que a bruxa tenha tornado a família um referencial para sua legitimação. Além da constatação de Mauss (1974) de que há, em diversas sociedades, famílias de mágicos, observa-se na wicca um recurso à família como ferramenta de legitimação da identidade de bruxa.

A identidade de bruxa, assim, é uma construção complexa que envolve, ao mesmo tempo, concepçóes de gênero ${ }^{11}$, concepçóes sobre o que é propriamente wiccano e o que não é (o que é cristão, por exemplo) e, ainda, concepçôes sobre os dons da bruxa e a presença de pessoas com tais dons na família da bruxa. 
A composição destes três elementos (gênero, wicca e dons) permite que se diga ser bruxa, que se legitime ou que se prove esta afirmação, ao mesmo tempo em que afasta acusaçóes contrárias que neguem que se é bruxa. Não se pode esquecer que a identidade, por mais que repouse em uma escolha, deve ser aceita socialmente (Goffman, 1999). No caso das bruxas pesquisadas, ser bruxa não aparece propriamente como uma escolha, mas como uma espécie de destino. Quando se diz ser bruxa "desde sempre", não há escolha possível. As narrativas das bruxas indicam claramente, neste sentido, uma busca, e não uma escolha, por uma religiosidade que exprime uma identidade multifacetada.

\section{Witches' gifts and wiccan trajectories: narratives about being and turning into a mo- dern witch.}

abstract Wiccans are in their majority women and designate themselves as witches. From the interviews realized with some wiccans in Rio de Janeiro, it has been possible to trace religious trajectories that begin within the religion adopted by the family (usually Catholic), changes to umbanda and kardecismo, finally arriving to New Age. Identifying themselves as witches, the interviewees redesign their past in a way to redefine certain events as marks of a witch career. To legitimate the "new" identity, some identify the power of the witch in women of their family, enabling themselves to affirm to be a witch "since ever".

keywords Wicca. Witchcraft. Identity. New Age. Gender.

\section{Notas}

1. Conforme o clássico estudo de Evans-Pritchard (1976) sobre os Azande e, no Brasil contemporâneo, por exemplo, o estudo de Maluf (1993) na Lagoa da Conceição, em Florianópolis, SC.
2. Adoto o plural no feminino referindo-me ao conjunto do universo pesquisado.

3. Embora um homem tenha sido entrevistado, mantive o plural no feminino.

4. O que se percebe em campo é que há a possibilidade de escolha de elementos de diversos espaços-tempos, mas que os pagãos europeus são os mais valorizados.

5. As informaçóes sobre o wicca foram produzidas a partir de uma gama de publicaçóes disponíveis sobre o assunto, cuja reprodução aqui não seria senão exaustiva. É uma informaçâo reproduzida, ainda, pelos próprios wiccanos, e que foi encontrada muitas vezes em diversas fontes na Internet. Conforme ficará claro ao leitor, tanto os livros quanto a Internet são fontes importantes de informaçáo para os wiccanos sobre sua própria prática religiosa.

6. Todos os nomes são fictícios.

7. Existem várias ediçôes distintas desta obra. Foi indicada uma delas, mas o leitor interessado perceberá que os títulos existentes hoje são distintos.

8. Os livros mencionados pelas entrevistadas estâo listados nas referências bibliográficas na medida em que podem ser de interesse do leitor e apresentados no formato ABNT no corpo do texto pela mesma razão. Levi (2003), Papus (1995), Coelho (1990), Bradley (1985) e Buonfiglio (1993; 1996), bem como O Tradicional Livro Negro de São Cipriano (1996), não são considerados wiccanos, daí sua identificação no começo da busca por uma religiosidade. Levi e Papus são classificados pelos wiccanos com quem convivi durante a pesquisa de campo como livros de magia cerimonial. Os wiccanos classificam a prática mágica a partir de uma série de categorias distintas pelas quais constroem uma relação de alteridade, que não explorei no presente artigo, mas que pode ser observada em Osório (2001). Esta foi uma opção metodológica para lidar com os livros e autores indicados nas entrevistas.

9. Para uma análise mais profunda sobre a importância da Internet no universo wiccano brasileiro, ver Osório (2005).

10. São respostas à seguinte pergunta: há alguém na sua família que você diria que é bruxa(o)? Essa pergunta foi formulada na medida em que o campo demonstrava uma tensão entre aqueles que recorriam a um antepassado bruxo e outros que atacavam tal tipo de interpretação do que é ser uma bruxa. Entre as entrevistadas há quase um consenso. Tal disputa foi descrita em outro lugar (Osório, 2005).

11. E não apenas entre as entrevistadas. Jones \& Valiente (1992, p. 17) frisam que "em momento algum afirmo 
que faz parte de uma tradição a mim transmitida por minha família. Ao contrário, trata-se de uma combinaçấo do antigo com o novo", ao se referirem ao sistema ritual que apresentam em seu livro.

12. A questâo racial que surge coloca negros e índios numa posição estruturalmente análoga à da mulher, portanto mais próximos à magia do que europeus.

13. Por questôes de espaço, as reflexões relativas à importância das relaçóes de gênero no universo pesquisado não puderam ser exploradas no presente artigo. Para maiores consideraçôes sobre o assunto, ver Osório (2004).

\section{Referências bibliográficas}

AMARAL, Leila. As implicaçôes éticas dos sentidos Nova Era de comunidade. Religião e Sociedade, n. 17/1-2, 1996. p. $54-74$.

BEAUVOIR, Simone de. O Segundo Sexo. Rio de Janeiro: Nova Fronteira, 1949.

BOURNE, Louis. Autobiografia de uma Feiticeira. Rio de Janeiro: Bertrand Brasil, 1985.

BRADLEY, Marion Zimmer. As Brumas de Avalon. 4vols. 19 ed. Rio de Janeiro: Imago, 1985.

BUONFIGLIO, Mônica. Anjos Cabalísticos. São Paulo: Oficina Cultural Esotérica, 1993.

. Almas Gêmeas. São Paulo: Oficina Cultural Esotérica, 1996.

COELHO, Paulo. Brida. Rio de Janeiro: Rocco, 1990.

CAROZZI, Maria Julia. "Nova Era: a autonomia como religião". In: A Nova Era no Mercosul. Petrópolis, Vozes, 1999. p. 149-190.

DOUGLAS, Mary. Pureza e Perigo. São Paulo: Perspectiva, 1976.

EVANS-PRITCHARD, E. E. Bruxaria, Oráculos e Magia entre os Azande. Rio de Janeiro: Zahar Editores, 1976.

GOFFMAN, Erving. A Representação do Eu na Vida Cotidiana. 8 ed. Petrópolis: Vozes, 1999.
GOLDENBERG, Mirian. A Outra. 6 ed. Rio de Janeiro: Revan, 1992.

GRIMASSI, Raven. Os Mistérios Wiccanos. São Paulo: Gaia, 2000.

HEELAS, Paul. A Nova Era no contexto cultural: pré-moderno, moderno e pós-moderno. Religiäo e Sociedade, n. 17/1-2, 1996. p. 15-32.

HOLZER, Hans. Como se iniciar na bruxaria: pequeno manual do bruxo e da feiticeira. 2 ed. Rio de Janeiro: Record, 1994.

JONES, Evan John; VALIENTE, Doreen. Feitiçaria: a Tradição Renovada. Rio de Janeiro: Bertrand Brasil, 1992.

LEVI, Eliphas. Dogma e Ritual de Alta Magia. São Paulo: Pensamento, 2003.

MALUF, Sônia. Encontros Noturnos. Rio de Janeiro: Rosa dos Tempos, 1993.

MAUSS, Marcel. "Esboço de uma teoria geral da magia". In: Sociologia e Antropologia. v.1. São Paulo: Edusp Epu, 1974. p. 37-176.

"A origem dos poderes mágicos nas sociedades australianas". In: OLIVEIRA, Roberto Cardoso de (org.). Antropologia. São Paulo: Ática, 1979. p. 60101.

O TRADICIONAL Livro Negro de São Cipriano. Rio de Janeiro: Pallas, 1996.

OSÓRIO, Andréa. Mulheres e Deusas: um estudo antropológico sobre bruxaria wicca e identidade feminina. Dissertação de Mestrado - Universidade Federal do Rio de Janeiro/PPGSA, Rio de Janeiro, 2001.

Bruxas modernas: um estudo sobre identidade feminina entre praticantes de wicca. Campos, n. 5/2, 2004. p. 159-172.

. Bruxas modernas na rede virtual: a Internet como espaço de sociabilidade e disputas entre praticantes de wicca no Brasil. Sociedade e Cultura, n. 8/1, 2005. p. 127-139.

PAPUS. Tratado Elementar de Magia Prática. São Paulo: Pensamento, 1995.

TURNER, Victor. O Processo Ritual. Petrópolis: Vozes, 1974.

autora Andreá Osório

Doutora em Antropologia / IFCS/UFRJ

Recebido em 30/01/2011

Aceito para publicação em 26/09/2011

cadernos de campo, São Paulo, n. 20, p. 51-64, 2011 